\author{
N.A. HUSSAIN ${ }^{1}$, A.K. NAIAMA ${ }^{1}$ and L.A.J.AL-HASSAN ${ }^{2}$
}

\title{
ANNOTATED CHECK LIST OF THE FISH FAUNA OF KHOR AL-ZUBAIR, NORTH WEST OF THE ARABIAN GULF, IRAQ
}

\section{FAUNA RYB Z KHOR AL-ZUBAIR W PÓŁN.-ZACH. ZATOCE ARABSKIEJ, IRAK}

\author{
${ }^{1}$ Marine Science Centre, University of Basrah, Basrah, Iraq \\ ${ }^{2}$ Dept. of Fisheries a Marine Resources, College of \\ Agriculture, University of Basrah, Basrah, Iraq
}

\begin{abstract}
The ichthyofauna of Khor Al-Zubair Area, North West of the Arabian Gulf is dominated by Clupeidae $(8,7 \%)$ and to a lesser extent by Dasyatidae, Carangidae, Sciaenidae and Mugilidae (5\%) for each of them. The total number of specics is 80 , belonging to 46 families.
\end{abstract}

\section{INTRODUCTION}

The Khor Al-Zubair is a North-West extension of the Arabian Gulf directed towards the inland waters of the lower Mesopotamia. It starts as a small bay north of Bubiyan Island and continues northwards until it ends in a number of small blind creeks just south of Zubair city, west of Basrah Fig. 1. Recently, this water extension of the Arabian Gulf has been connected with the lower reaches of Al-Hammar marsh by a water channel (Basrah River).

The length of Khor Al-Zubair is about 40 Kilometers (Al-Katib, 1971). The environmental characters of this area is similar to the north part of the Arabian Gulf.

The fish fauna of Khor Al-Zubair is more or less similar to those of the Arabian Gulf on which the first systematic work was published in 1905 by Regan. Important contributions to the ichthyofauna of the Arabian Gulf include Blegvad (1944), Al-Daham (1982), Sivasubramanian and Ibrahim (1982), Kuronoma and Abe (1986), and Al-Baharna (1987).

The purpose of this paper is to provide a provisional list of Khor Al-Zubair fishes in order to facilitate further studies on this fauna by interested workers. The provisional nature of the present list is occasional by the poor state of the present knowledge on the 


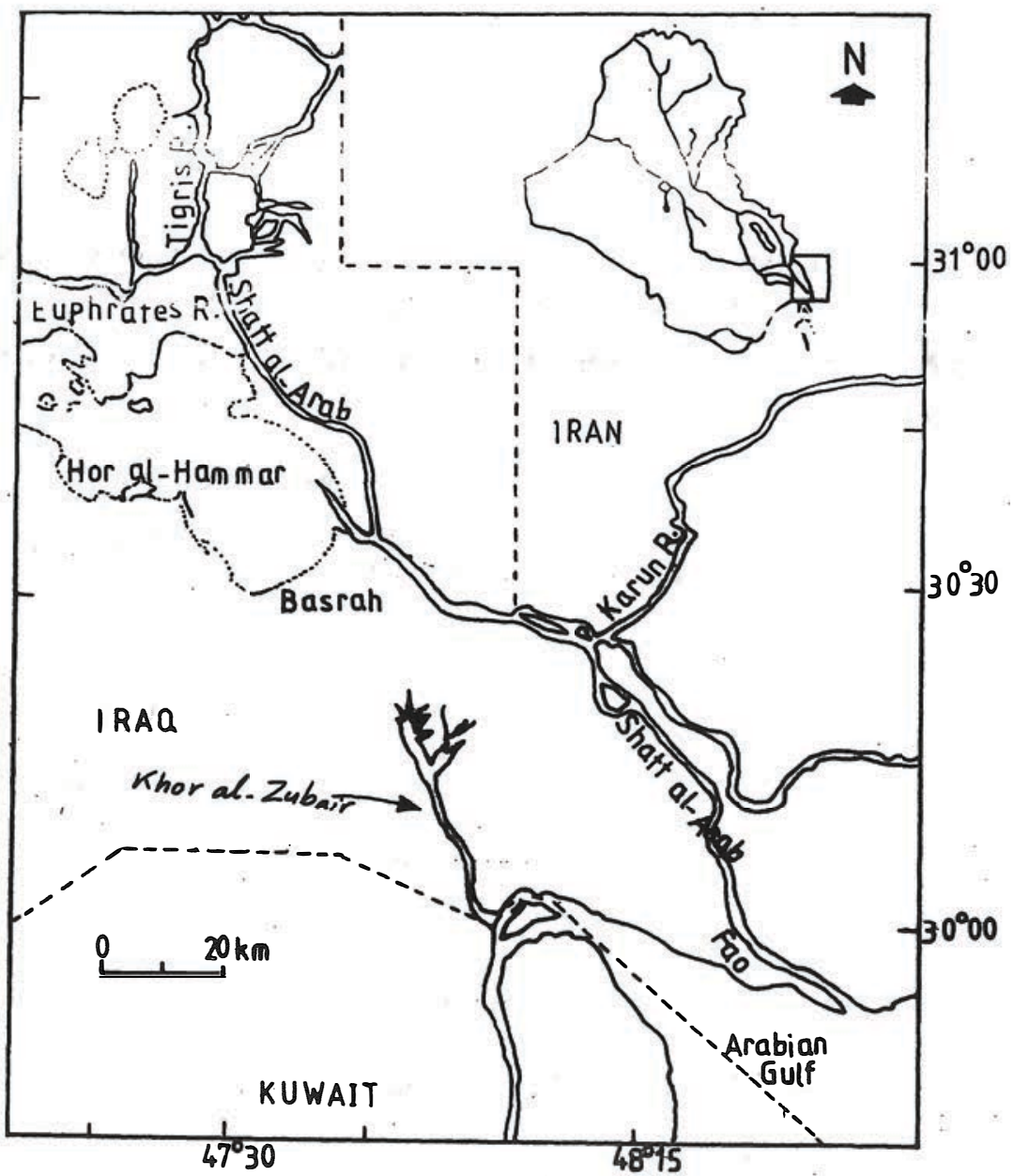

Figure 1. Map showing sampling area

systematics of fishes from Khor Al-Zubair area in particular and the Arabian Gulf in general. This list gives an idea about what species of fishes are found in the north west extension of the Arabian Gulf because the northern part of the gulf cannot be assumed to have the same species as the mid and southern parts.

\section{MATERIALS AND METHODS}

Fishes were captured by fixed gill nets, drifting nets, shrimp trawl net, Beach sein net and Beam trawl during the period 1984-1987. Orders and families were arranged systematically according to Nelson (1976) while Sharks and rays is based on the system of Compagno (1973). Species were listed alphabatically under each family. 


\section{RESULTS}

A total of 80 species belonging to 40 families were recorded. An annotated list of the species is presented below.

Class: CHONDRICHTHYES

Order: RAJIFORMES

Family: Rhinobatidae

Rhinobatus granulatus Cuvier, 1829

Order: PRISTIFORMES

Family' Pristidae

Pristis cuspidatus Latham, 1909

Order: MYLIOBATIFORMES

Family: Dasyatidae

Dasyatis gerrardi (Gray, 1851)

Dasyatis imbricatus Bloch\&Schneider, 1801

Hypolophus sephen (Forsskal, 1775)

Himantura urank (Forsskal, 1775)

Family: Myliobatidae

Aetomylaeus nichoffi (Bloch\&Schneider, 1801)

Family: Mobulidae

Mobula diabolus (Shaul, 1804)

Order: ORECTOLOBIFORMES

Family: Hemiscyllidae

Chiloscyllium arabicum Gubanov, 1980

Chiloscyllium griseum Miuller \& Henle, 1841

Order: CARCHARHINIFORMES

Family: Carcharhinidae

Carcharhinus dussumieri (Valenciennes in Müller et Henle, 1839)

Carcharhinus leucas (Valenciennes, 1839)

Carcharhinus melanopteras (Guoy et Gaimard, 1824)

Class: OSTEICHTHYES

Order: CLUPEIFORMES

Family: Clupeidae

Anodontostoma chacunda (Hamilton-Buchanan, 1822)

Ilisha megaloptera

Ilisha melanostoma (Schneider, 1801)

Nematalosa arabica Regan, 191

Nematolosa nasus (Bloch, 1795)

Sardinella albella (Valenciennes, 1795)

Tenualosa ilisha (Hamilton-Buchanan, 1822)

Family: Engraulidae 
Thryssa dussumeiri (Valenciennes, 1795)

Thryssa hamiltoni (Gray, 1835)

Thryssa mystax (Schneider, 1801)

Family: Chirocentridae

Chirocentrus dorab (Forsskal, 1775)

Order: AGUILIFORMES

Family: Muraenesocidae

Muraenosox cinereus (Forsskal, 1775)

Order: $\quad$ CYPRINIFORMES

Family: Cyprinidae

Alburnus capito

Order: SULURIFORMES

Family: Heteropneustidae

Heteropneustis fossilis (Bloch, 1801)

Family: Ariidae

Arius thalassinus (Rueppel, 1835)

Order: MYCTOPHIFORMES

Family: Synodontidae

Saurida undosquamis (Richardson, 1848)

Order: GADIFORMES

Family: Bregmacerotidae

Bregmaceros macclellandii (Munro, 1950)

Order: ATHERINOFORMES

Family: Hemiramphidae

Hemiramphus limbatus

Family: Belonidae

Strongylura strongylura (Van Hasselt, 1823)

Order: GASTROSTEIFORMES

Family: Syngnathidae

Hippocamcus kuda

Order: SCORPAENIFORMES

Family: $\quad$ SYNANCEIDAE

Pseudosynancia melanostigma (Day, 1878)

Family: Platycephalidae

Platycephalus indicus (Linnaeus, 1758)

Order: PERCIFORMES

Family: Serranidae

Epinephelus areolatus (Forsskal, 1775)

Epinephelus tauvina (Forsskal, 1775)

Family: Theraponidae

Therapon puta Cuvier et Valenciennes, 1829) 
Family: Sillagnidae

Sillago sihama (Forsskal, 1775)

Family: Carangidae

Atule djedaba (Forsskal, 1775)

Caranx para (Cuvier, 1933)

Scomberoides lysan (Forsskal, 1775)

Selar crumenophthalmus (Bloch, 179.3)

Family: Leiognathidae

Leiognathus bindus (Valenciennes, 1835)

Family: Nemipteridae

Nemipterus japonicus (Bloch, 1791)

Family: Pomadasyidae

Pomadasys argenteus (Forsskal, 1775)

Pomadasys maculatus (Bloch, 1793)

Family: Sparidae

Acanthopagrud berda (Forsskal, 1775)

Acanthopagrus latus (Houtuyn, 1782)

Sparidentex hasta (Valenciennes, 1830)

Family: Sciaenidae

Johnius sina (Cuvier, 1830)

Johnius elongatus Mohan, 1976

Otolithes ruber (Schneider, 1801)

Protoniba alicanthus (Lacépèds, 1802)

Family: Mullidae

Upeneus asymmetricus Lachner, 1954

Upeneus sulphureus Cuvier et Valenciennes, 1829

Upeneus vitatus

Family: Scatophagidae

Scatophagus argus (Bloch, 1788)

Family: Mugilidae

Liza abu (Heckel, 1846)

Liza carinata (Valenciennes, 1836)

Liza macrolepis (Smith, 1849)

Liz a subviridis (Valenciennes, 1836)

Family: Polynemidae

Eleutheronema tetradactylum (Shaw, 1804)

Polydactylus sextarius (Bloch et Schneider, 1801)

Family: Scaridae

Scarus ghobban Forsskal, 1775

Family: Gobiidae

Bathygobius fuscus (Rueppell, 1828) 


\author{
Periophthalmus waltoni Kuomans, 1941 \\ Pseudopocryptes dentatus (Valenciennes, 1837) \\ Family: Trypauchenidae \\ Trypauchen vagina (Bloch et Schneider, 1801) \\ Family: Siganidae \\ Siganus canaliculatus (Park, 1797) \\ Family: Trichiuridae \\ Trichiurus lepturus (Linnaeus, 1758) \\ Family: Stromateidae \\ Pampus argenteus (Euphrasen, 1788) \\ Order: PLEURONECTIFORMES \\ Family: Psettodidae \\ Psettodes erumei (Bloch et Schneider, 1801) \\ Family: Bothidae \\ Pseudorhombus arsius (Hamilton, 1822) \\ Family: Soleidae \\ Euryglossa orientalis (Bloch et Schneider, 1801) \\ Family: Cynoglossidae \\ Cynoglosus arel (Schneider, 1801) \\ Family: Triacanthidae \\ Pseudotriacanthus strigilifer (Cantor, 1849)
}

\title{
DISCUSSION
}

The number of the recorded families in the Arabian Gulf vary widely, according to the place of sampling, Blegvard (1944) recorder seventy families from the Iranian side of the Gulf, Relyea (1981) counted six ty six families from the Kuwaiti waters, Sivasubramanian and Ibrahim (1982) reported fifty four families from Qatari waters. However, Kuronuma and Abe (1986) recorded one hundred and one families from the entire Gulf region. In our survey, forty six families were recorded. Thirteeen of which were represented by more than one specimen, the rest by a single species. The richest family was Clupeidae represented by seven species.

Kuronoma and Abe (1986) mentioned thirteen families as the most domenant families in the Arabian Gulf (Garangidae, Lutjanidae, Pomadasyidae, Gobiidae, Clupeidae, Serranidae, Sparidae, Carcharhinidae, Apogonidae, Sciaenidae, Blennidae, Bothidae and Scombridae). Four of them were absent from the Khor (Lutianidae, Agonidae, Blennidae and Scombridae), this may be due to that the first three families are common on rocky shores and coral reefs, taking in cansideration that no rocky shores or coral reefs exists in Khor Al-Zubair, however, Scombridae was known to be migratory family from the Gulf of Oman to the Arabian Gulf (Suda, 1973) and no larval form were recorded in the Gulf region (Nellen, 1973). 
Estuarine freshwater species were represented in the Khor by Liza abu. Alburnus capito and Heteropneustes fossilis, there were certain factors which contributed to the establishment of relatively small populations of these species, one of the major factor is the influx of freshwater-through the dam to the Khor area which dilute the Khor's water. These species were catch during February and March of the year salinity is in its minimum range during the whole year (abour 12\%). Baside several freswater fish species were observed in the upper reaches of the Khor near the freshwater influx from the marsh area such as Barbus grypus, Barbus luteus, Barbus sharpeyi, Parasilurus triostegus.

In terms of the cartilagenous species, it would clearly appear from the results that theis group is poorly represented in the Khor, the same was found in Kuwait Bay and the Khors of the United Arab Emirates (AOAD, 1976, Dames a . Moores, 1981).

Illisha megaloptera, Nematalosa arabica and Caranx para were recorded for the first time from the first time from the Arabian Gulf, while Pristis cuspidatus, Dasyatis imbricatus, Aetomylaeus nichoffi and Anodontostoma chaounda were the first record for the Iraqi marine waters.

\section{ACKNOWLEDGEMENT}

Our sincere thanks are due to Dr. Brian W. Coad National Museums of Canada and to Dr. Peter Whitehead of Zoology Dept. British Museum (Natural History), London for their help in the identification of the specimens that show a problem in their identification.

\section{REFERENCES}

Al-Baharna W., 1986: Fishes of Bahrain, Ministry of Commerce and Agriculture, Directorate of Fisheries, Manama, Bahrain.

Al-Daham N.K., 1982: The ichthy ofauna of Iraq and the Arab Gulf. A check-list. Basrah Nat. Hist. Mus. Publication No.4.

Al-Katib M.T., 1971: Shatt AlArab, Shatt Al-Basrah and the history. Basrah Directorate of Ports Press. (in Arabic).

Arabic Organisation for Agriculture Development, 1976: Survey and Development of inland fisheries of Khores in the United Arab Emirates. Arab League (AOAD) (in Arabic).

${ }^{1}$ Blegvad H., 1944: Fishes of the Iranian Gulf. Danish Scientific Investigations in Iran.3.

Compagno K.J.V., 1973: Interrelationships of living elasmobranches. In: Interralationships of fishes. Zool. J. Linn. Soc. 53 (Suppl. 1): 15-16.

Dames and Moore 1981: Summary report on ocenography of Kuwait Bay performed by Dames and Moore environmental Laboratories in Kuwait for Kuwait water and electrical authority.

Kuronuma K. and Abe Y., 1986: Fishes of the Arabian Gulf. Kuwait Inst. Sci. Res., Kuwait.

${ }^{1}$ Nellen W., 1973: Kinds and abundance of fish larvae in the Arabian Sea and the Persian Gulf. In: The Biology of the Indian Ocean. Springer-Verlag, Berlin.

Nelson J.S., 1976: Fishes of the world, John Wiley and Sons, New York. 
${ }^{1}$ Regan T., 1905: On the fishes from the Persian Gulf, the sea of Oman, and Karachi collected by F.W. Townsend. J. Bombay nat. Hist. 16/2/.

Relyea K., 1981: Inshore fishes of the Arabian Gulf. George Allen Unwin, London.

Sivasubramanian K. and Ibrahim M.A., 1982: Comon fishes of Qatar.

Suda A., 1973: Tuna fisheries and their resources in the Indian Ocean In: The Biology of the Indian Ocean. Springer Verlag, Berlin, 431-449.

1) Persian Gulf means Arabian Gulf.

N.A. Hussain, A.K. 'ama i L.A.J. Al-Hassan

FAUNA R YB Z KHOR Al-ZUBAIR W PÓŁN.-ZACH. ZATOCE ARABSKIEJ IRAK

STRESZCZENIE

Autorzy podają spis 80 gatunków ryb złowionych w latach 1984-1987 ze zbiornika bezpośrednio związanego z Zatoką Arabską. Obejmuje on gatunki z 46 rodzin, głównie Clupeidae $(8,7 \%)$, Dasyatidae, Carangidae, Sciaenidae i Mugillidae (5\%).

Authors' addresses:

Received: 88.06 .15

N.A. Husain

A.K. Na'ama

University of Basrah

Marine Science Centre

Basrah - Iraq

L.A.J. Al-Hassan

University of Basrah

College of Agriculture

Dept. of Fisheries a. Marine Desources

Basrah Iraq 